\title{
Industrial influence on glacial processes in mountains of circumpolar regions
}

\author{
V. I. Grebenets and D. B. FedoseyeV \\ Gersevanov Research Institute of Bases and Underground Structures, Noril'sk, USSR
}

\begin{abstract}
Industrial activity in the Noril'sk mountains since the 1930s has changed the landscape and formed artificial banks, ridges and terraces. New water courses have been formed and snow has been removed to places where it has accumulated year by year. The ground temperature has increased by 0.3 to $0.5^{\circ} \mathrm{C}$ down to a depth of 30 to $50 \mathrm{~m}$, melting has increased in the permafrost layer and artificial ground has become more unstable, leading to landslides and mudflows. Material in dumping sites has frozen and turned into rock glaciers, chemical pollutants have accumulated in snow and extremely high concentrations are observed in meltwater during spring. The gravitational instability of mountain and piedmont landscapes increases with human activities and the landscapes thus changed cause greater danger from slumps, mud flows and avalanches.
\end{abstract}

\section{INTRODUGTION}

The plateau of Putorana is situated north of the Arctic Circle. It is the most uplifted part of central Siberia with altitudes between 1000 and $1500 \mathrm{~m}$. The glaciers are mainly located in cirques and structural ledges of the northern mountain slopes. There are 22 cliff and cirque glaciers with the total area of $22 \mathrm{~km}^{2}$. Glacier surfaces are steep, both in the accumulation and ablation zones. The contemporary glaciation of the plateau and the different glacial forms and deposits confirm the large-scale Pleistocene glaciation of this region. The region is also characterized by the distribution of continuous permafrost.

Glacial and cryogenic phenomena are found here because of the severe climatic conditions (average annual temperature in Noril'sk is $-9.2^{\circ} \mathrm{C}$ ) and high altitudes. Cryogenic erosion processes are active in this place. Stone polygons and rings occur on the plane surfaces; stone strips, rock screes, solifluction and nivation relief forms can be observed at the foothills and on mountain slopes. There are many glacial lakes in the mountain valleys, which are dammed by moraines.

Industrial activity on the Noril'sk plateau started in the 1930s (Fig. 1). Extraction of useful minerals and rapid construction at industrial rates (mining and metallurgical industries) have transformed the natural environment. Thousands of tons of sulphur dioxide, metallic waste material and other pollutants are being released into the atmosphere, hydrosphere and lithosphere every year; the extraction of useful minerals is conducted both in mines and in quarries; poor rock and rubbish heaps are accumulated upon mountain slopes; fluid and solid metallurgical waste materials are stored in special places, and hydrotechnical constructions protect nature

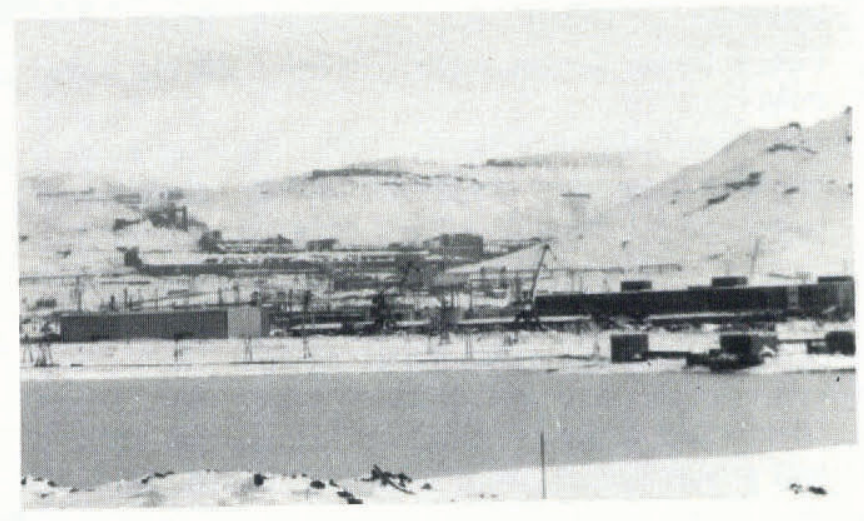

Fig. 1. Industrial occupation of the piedmont plains of Noril'sk plateau.

and people from chemical contamination. Hence, the Noril'sk region could be taken as an example of the extremely negative effect of human activities and technological influence on mountain territories.

\section{GEOTHERMAL REGIME AND TECHNO- CRYOGENIC PROCESSES}

Urban territory is the epicentre of anthropogenic violations! Twenty years of in situ observations of the geothermal conditions at depths of 30 to $50 \mathrm{~m}$ in the central part of the urban zone showed a rise in ground temperatures of between 0.3 and $0.5^{\circ} \mathrm{C}$, while a similar trend in air temperature is absent (Grebenets, 1989). Heating the upper layers of permafrost causes water saturation of the ground and the thickness of the 
seasonally melted layer increases. Most of the industrial activity is centred at the mountain slopes with average steepnesses of 8 to $15^{\circ}$. Artificially frozen ground is used in the construction of foundations. Water saturation of the artificially frozen ground incites solifluction (fast solifluction is frequent). Different relief forms arise, such as banks, ridges and terraces.

Mechanical breaching and loosening of rocks under roads and building works activates erosional processes.

The roads on the slopes, long building constructions and different objects change the orohydrogeography of the foothills. Temporary and permanent water courses arise. Deposits of quarried rocks and rubbish heaps dam the natural water courses; this leads to the beginning of man-made screes, landslides and mudflows.

Summer is the time when the erosional processes are most active and most degradation takes place. During winter, conditions are favourable for the nourishment of glaciers and snowbanks. The average annual precipitation is over $1000 \mathrm{~mm}$. At elevations above $800 \mathrm{~m}$ most of the precipitation is solid. The distribution of snow cover is affected by the relief and vegetational features as well as by man's activities.

Artificial accumulation of snow takes place at the time of road clearing, when snow is removed from the urban areas. The snow is collected in snowbanks from year to year. The thickness of the artificial snowbanks is 10 to $12 \mathrm{~m}$ at the end of the accumulation season and 3 to $5 \mathrm{~m}$ at the end of the summer.

\section{CHEMICAL POLLUTION OF THE SNOW}

The snow surface in the industrial zone is covered by a thick layer of dust which accumulates during the winter. The metallurgical plants here throw into the atmosphere 2.4 million tons of sulphur dioxide and several thousands of tons of dust and other air pollutants. When mixed with rain, pollutants penetrate the upper ground layers. The thickness of the active layer increases, cohesion of the ground particles becomes smaller and the activity of cryogenic processes on the slopes rises. Various chemical elements accumulate in the active layer.

In 198:? a huge metallurgical plant was built in Noril'sk anc the emission of the pollutants rose 1.3 times. The concen:ration of chemical elements in the seasonally melted layer has grown considerably from that time. The analyses of the ground water samples from this layer are shown in Table 1 .

As most of the precipitation is solid, the pollutants accumulate in the seasonal snow cover, artificial snowbanks and glaciers. When this snow melts, some of the pollutants penetrate the active soil layer. The analyses of the snow samples are shown in Table 2. As shown in this table, large concentrations of $\mathrm{SO}^{2-}$ and some other pollutants can be found in snow samples near Noril'sk. Dissolved chemical substances increase the technogenic salinity of snow. The main cause of the pollution is emissions from metallurgical plants.

The transformation of snow structure occurs under heat and the mechanical influence of dust, which leads to the formation of friable layers in the snow. Hence, the danger of avalanches is increased. Further mechanical
Table 1. Analyses of ground water samples, in $m g L^{-1}$, for Noril'sk, Siberia

18 September 1977

19 March 1990

Number of sample

$\begin{array}{llll}1 & 2 & 3 & 4\end{array}$

\begin{tabular}{lrrrr}
\hline & & & & \\
$\mathrm{Ca}^{2+}$ & 148 & 188 & 1078 & 1114 \\
$\mathrm{Mg}^{2+}$ & 43 & 46 & 20 & 81 \\
$\mathrm{Na}^{+} \mathrm{K}^{+}$ & 68 & 149 & 456 & 401 \\
$\mathrm{Cl}^{-}$ & 46 & 39 & 118 & 38 \\
$\mathrm{SO}_{4}{ }^{2-}$ & 389 & 784 & 2502 & 3009 \\
$\mathrm{HCO}_{3}{ }^{-}$ & 214 & 311 & 1416 & 1250 \\
$\mathrm{NH}_{4}{ }^{-}$ & - & - & 174 & 60 \\
$\mathrm{Ni}^{-}$ & - & - & 0.2 & 0.3 \\
$\mathrm{Cu}$ & - & - & 1.0 & 1.1 \\
& & & & \\
$\mathrm{pH}$ & 7.7 & 8.2 & 7.8 & 7.6 \\
& & & & \\
\hline
\end{tabular}

(- : not determined)

Table 2. Analyses of the snow samples, concentrations, 1990, in $m g L^{-1}$, for Noril'sk, Siberia

\begin{tabular}{lcccccc} 
No. & 1 & 2 & 3 & 4 & 5 & 6 \\
\hline & & & & & & \\
$\mathrm{Ca}^{2+}$ & 23.2 & 3.0 & 10.4 & 11.2 & 8.2 & 1.6 \\
$\mathrm{Mg}^{2+}$ & 12.7 & 0.3 & 7.7 & 15.6 & 1.9 & 1.4 \\
$\mathrm{Na}^{+} \mathrm{K}^{+}$ & 4.7 & 8.5 & 0.36 & 0.44 & 0.22 & 0.49 \\
$\mathrm{Cl}^{2-}$ & 5.0 & 3.3 & 0.53 & 0.65 & 0.28 & 0.43 \\
$\mathrm{SO}_{4}{ }^{2-}$ & 369.3 & 3.7 & 23.2 & 22.4 & 4.4 & 0.8 \\
$\mathrm{HCO}_{3}{ }^{-}$ & 80.0 & 25.1 & 42.7 & 74.2 & 30.26 & 9.76 \\
$\mathrm{NH}_{4}{ }^{-}$ & 0.1 & - & 1.53 & 0.61 & 1.16 & 0.54 \\
$\mathrm{NO}_{3}{ }^{-}$ & 0.58 & - & 0.15 & 0.16 & 0.07 & 0.09 \\
$\mathrm{Ni}^{-}$ & - & - & 0.4 & 0.0 & 0.0 & 0.0 \\
$\mathrm{Cu}^{-}$ & 14.5 & - & 0.4 & 0.4 & 1.0 & 0.1 \\
$\mathrm{pH}$ & 2.7 & 7.0 & 10.04 & 10.51 & 7.4 & 6.74 \\
& & & & & & \\
\hline
\end{tabular}

(- : not determined)

sample 1: metallurgical plant

samples 2-5: border of the Noril'sk urban zone

sample 6: $150 \mathrm{~km}$ from Noril'sk

violations during underground explosions, earthworks, skiing and so on result in unexpected snow release. Besides that, dust cover with a thickness of 20 to $50 \mathrm{~mm}$ prevents the snow from melting. 


\section{GLAGIAL PHENOMENA INFLUENGED BY INDUSTRIAL ACTIVITY}

Glacial technogenic phenomena include the formation of artificial snowbanks, rock glaciers and different relief forms. Long-term dumping sites for accumulation and conservation of the metallurgical waste material cause ecological problems. Deposits of chemically saturated solid and fluid products rise to heights of 40 to $50 \mathrm{~m}$. Ground dikes with frozen filtration cores surround the artificial hills. The safety of the natural surroundings and of the people depends on the reliability of these dikes.

Water-saturated deposits freeze on the mountain slopes, their thickness increases year by year and they start to move as rock glaciers. The dynamics of these rock glaciers has not been studied yet, but they can be dangerous for constructions, including buildings and roads. They are created layer by layer and thin horizontal portions of ice appear annually. The concentration of ice is very high. Due to the rheological properties of these artificial structures, they are more dangerous than natural rock glaciers.

\section{CONCLUSIONS}

Noril'sk mountain region can be considered to be a model for studying the evolution of natural landscapes under the influence of anthropogenic activities. Arctic mountain and piedmont landscapes are most vulnerable, and gravitational instability increases with man's influence. Dangerous glacial and cryogenic processes become more active. Increase of temperatures in the frozen ground and retreat of permafrost lead to increasing costs of the construction of roads and the exploitation of minerals (Mezenskiy and Grebenets, 1989). Different technical methods, including artificial ground freezing, help to stabilize the permafrost situation (Grebenets, 1990). A cautious attitude to the environment, and continuing studies of the processes and negative effects of industrial activities, are necessary for the sustainable development of the circumpolar regions.

\section{REFERENCES}

Grebenets, V.I. 1989. Izmeneniye pod vliyaniyem zastvoyki geokriologicheskoy obstanovki v $\mathrm{g}$. Noril'ske [Permafrost changes under building constructions in Noril'sk]. In Problemy inzenerno-geologicheskikh izyskaniy $v$ kriolitozone [Problems of engineering-geological investigations in the permafrost zone]. Magadan, Gosstroy RSFSR, 328-331.

Grebenets, V.I. 1990. Antifiltration curtains construction with the natural cold utilization. In Price, D. G., ed. Proceedings of the 6th International IAEG Congress, Rotterdam, 6-10 August, 1990. Rotterdam, A. A. Balkema, 1285-1287.

Mezenskiy, V.I. and V.I. Grebenets. 1989. Technical methods in the time of Noril'sk town building. In Geocryology of the USSR. Middle Siberia. Moscow, Nedra, 336-342. [In Russian.]

The accuracy of references in the text and in this list is the responsibility of the author/s, to whom queries should be addressed. 